\title{
Fairness a slippery concept: The common law of contract and the Consumer Protection Act 68 of 2008
}

Yeukai Mupangavanhu

$L L B$ LLM LLD

Senior Lecturer, Faculty of Law, University of the Western Cape

\section{OPSOMMING}

Billikheid is 'n Glibberige Konsep: Die Gemeenregtelike Kontraktereg en die Wet op Verbruikersbeskerming 68 van 2008

Die kontraktereg is in die verlede gekritiseer, onder andere vir die volgende redes: eerstens, vir die klassieke libertynse grondslag daarvan; tweedens, omdat dit nie grondwetlike waardes ten volle omsluit het nie; en, laastens, omdat dit daarvan weggeskram het om aan regverdigheid en billikheid uiting te gee in die aanwending van tersaaklike regsreëls. Die kwessie of howe na behore 'n balans tref tussen kontrakteervryheid en pacta sunt servanda enersyds, en billikheidsoorwegings andersyds bly een van die probleme wat die moderne kontraktereg in die gesig staar. Heelwat gewysdes dui daarop dat howe voorkeur verleen aan pacta sunt servanda bo billikheidsoorwegings aangesien die howe daarna streef om reg- en handelsekerheid te verseker deur die handhawing van kontrakte wat vrylik deur die partye daartoe gesluit is, al is die kontrakte somtyds onbillik. Die Wet op Verbruikersbeskerming 68 van 2008 (WOV) het ten doel om, onder andere, die sosiale en ekonomiese belange van Suid-Afrikaanse verbruikers te bevorder, billike besigheidspraktyke aan te moedig, en verbruikers teen gewetenlose, onregverdige en onbehoorlike besigheidspraktyke te beskerm. Die doel van hierdie artikel is om te bepaal of die regspaternalisme onderliggend tot die uitvaardiging van die WOV wel daarin slaag om van die kritiek aan te spreek wat in die verlede teen die gemeenregtelike kontraktereg geopper is, by uitstek ten opsigte van die billikheidskwessie.

\section{Introduction}

"This is a court of law, young man, not a court of justice". ${ }^{1}$

The principles of freedom and sanctity of contract are rooted in the political and economic philosophies of laissez-faire liberalism and individualism. ${ }^{2}$ This classical model of law is based on the assumption that parties generally have a real freedom of choice and that parties enjoy more or less equal bargaining power. ${ }^{3}$ Parties are thus free to accept or

1 Oliver Wendell Holmes as quoted by Walters Justice is God's idea: Man has corrupted and destroyed it! (2012) 24.

2 Hutchison \& Pretorius (eds) The Law of Contract in South Africa (2012) 23.

3 Idem 24.

How to cite: Mupangavanhu 'Fairness is a slippery concept: The common law of contract and the Consumer http/ldx.doi.org/10.17159/2225-7160/2015/v48nta 
reject any terms of a contract. The classical model of law is based on the assumption that there is near perfect competition in the market, and that parties actually negotiate the terms of their contract. ${ }^{4}$ Although it is axiomatic that these assumptions are incorrect, contract law remains a domain where individual autonomy finds prominent expression. ${ }^{5}$ Contractual autonomy, and the consent of the parties, is the basic legitimating factors behind the binding force of a contract. Finding the right balance between freedom and sanctity of contract, and considerations of fairness, remains one of the problems facing modern contract law. ${ }^{6}$ Much of the jurisprudence shows that sanctity of contract prevails over fairness as courts seek to promote legal and commercial certainty by enforcing contracts that are freely and properly entered into by the parties, even if they are sometimes unfair. ${ }^{7}$

The first part analyses the question whether the common law of contract has fully embraced constitutional values to import fairness into contractual relations. This question remains unanswered not only in South Africa, but in other countries as well. This state of affairs has resulted in governments intervening in markets across the globe to alleviate poverty and some of the hardships caused by unbridled capitalism, particularly in consumer contracts. ${ }^{8}$ The rationale behind contract regulation and legal paternalism through the enactment of the Consumer Protection $\mathrm{Act}^{9}$ (CPA) is to control the exercise of power and ensure fairness in contractual relations. The main aim of this article is to assess whether legal paternalistic interventions by the State, through the enactment of the CPA, is a solution for the problem of infiltrating the application of rules in contract law with equity and fairness. It is argued that healthy legal paternalism is crucial in any given society as it can be a vehicle for addressing the problem of balancing sanctity of contract with fairness. However, the effectiveness of the CPA in doing so remains to be seen.

The second part examines the extent to which the law of contract has embraced constitutional values in view of the fact that the Constitution of the Republic of South Africa, 1996 (the Constitution) is the supreme law of the land. It also discusses the interaction between sanctity of contract and fairness, as well as equity in terms of the common law of contract. The discussion also deals with how fairness is generally imported into the common law of contract, and the extent to which courts are prepared to balance the competing goals. The third part assesses the role of the CPA as an instrument that has been designed to promote fair business practices and to protect consumers from

$4 \quad$ Ibid.

5 Cserne Freedom of Contract and Paternalism: Prospects and Limits of an Economic Approach (2012) 81.

6 Hutchison \& Pretorius 22.

7 Barkhuizen v Napier 20075 SA 323 (CC); Afrox Healthcare Bpk v Strydom 20026 SA 21 (SCA); Brisley v Drotsky 20024 SA 1 (SCA).

8 Hutchison \& Pretorius 24.

968 of 2008. 
unconscionable, unreasonable, unjust or improper trade practices. ${ }^{10}$ The provisions of the CPA that have an impact on contract law are specifically analysed. The last part will include a conclusion.

\section{Has the Common Law of Contract Fully Embraced Constitutional Values?}

\section{Introduction}

Contract law basically deals with contractual private dealings and thus regulates socio-economic relationships in the private sphere. ${ }^{11}$ The common law of contract refers to the law made by the courts as opposed to the law made by the legislature. ${ }^{12}$ Judges make such law by interpreting already existing and established rules of law when resolving contractual disputes. Common law is thus an uncodified body of law that is developed through the doctrine of stare decisis. ${ }^{13}$ By its nature, common law needs to be modified, extended or supplemented to ensure that it is in tune with societal social needs and values. ${ }^{14}$ Mupangavanhu thus argues that it is within this context that courts are expected to develop the common law, ${ }^{15}$ as required in terms of section 39(2) of the Constitution. ${ }^{16}$ Courts should adapt the common law in accordance with the spirit, purport, and objects of the Bill of Rights.

The Constitution is founded on the values of human dignity, equality and freedom. ${ }^{17}$ The question that arises is: To what extent has the common law of contract embraced constitutional values? Inequalities in bargaining power in South Africa are underscored by deeply entrenched social and economic inequalities, occasioned by apartheid and patriarchy. ${ }^{18}$ Bhana argues that the value of equality requires evidence of unequal bargaining power to be taken into account, so as to ensure that there is autonomy in substance as opposed to mere form. ${ }^{19}$ The move towards the concept of substantive consensus, that takes better

10 Part F ss 40-47 CPA

11 Bhana 'The Role of Judicial Method in the Relinquishing of Constitutional Rights Through Contract' 200824 SAJHR 300303.

12 Currie \& De Waal The Bill of Rights Handbook (2005) 67. See also Du Bois (ed) Wille's Principles of South African Law (2007) 64

13 Mupangavanhu 'Yet Another Missed Opportunity to Develop Common Law of Contract? An Analysis of Everfresh Market Virginia (Pty) Ltd $v$ Shoprite Checkers (Pty) Ltd (2011) ZACC 30'2013 Speculum Juris 148150.

14 Brand 'The Role of Good Faith, Equity and Fairness in the South African Law of Contract: The Influence of the Common Law and the Constitution' 2009 SALJ 7172.

15 Mupangavanhu 2013 Speculum Juris 148150

16 S39(2) provides: "When interpreting any legislation, and when developing the common law or customary law, every court, tribunal or forum must promote the spirit, purport and objects of the Bill of Rights".

17 S 1 of the Constitution,

18 Bhana \& Pieterse 'Towards a reconciliation of contract and constitutional values: Brisley and Afrox Revisited' 2005 SALJ 865887.

19 Bhana supra $\mathrm{n} 11$ at 301 
cognisance of the inequalities prevalent in South Africa, is a dream which has to be realised in contract law. ${ }^{20}$ There is need for an incremental development of contract doctrines to achieve a balance between the values of freedom and equality. ${ }^{21}$ Bhana and Pieterse opine that courts should be willing to infuse contract doctrines with values underlying the Constitution. $^{22}$ Courts must not shy away from developing common law to ensure that the law responds to the general needs of the people.

Everfresh Market Virginia (Pty) Ltd $v$ Shoprite Checkers (Pty) Ltd ${ }^{23}$ involved an application for leave to appeal which required the Court to consider the circumstances in which it should intervene to infuse the law of contract with constitutional values. The applicant argued directly for the development of the common law of contract in light of the spirit, purport and object of the Bill of Rights, but only in the Constitutional Court. ${ }^{24}$ The majority of the judges held that: "It would not be in the interests of justice to remit this matter to the High Court on the narrow ground that it ought to have investigated the possible adaptation of the common law of its own volition". 25

The application for leave to appeal thus failed. ${ }^{26}$ It has been argued that the Constitutional Court missed the opportunity to develop the duty to negotiate in good faith beyond precedent in this case. ${ }^{27}$ Although the case was not properly pleaded, ${ }^{28}$ it cannot be gainsaid that the Court should have developed good faith to become enforceable as an independent rule so as to actively promote contractual fairness. ${ }^{29}$ It remains to be seen whether the current role that good faith plays will be developed.

\section{The Need for Certainty Versus the Need for Good Faith and Equity}

\section{Freedom and Sanctity of Contract}

It is becoming axiomatic that sanctity of contract and fairness are competing values that need to be balanced by courts. Freedom of contract means that parties are free to decide whether or not to contract; with whom and on what terms. ${ }^{30}$ Ideally, the creation of a contract should be the result of a free choice, without external interference, and that in the process of contracting, the parties are sovereign. Once a court

20 Bhana \& Pieterse 2005 SALJ 865887.

21 Idem 889.

22 Ibid.

23 Everfresh Market Virginia (Pty) Ltd v Shoprite Checkers (Pty) Ltd 20121 SA 256 (CC).

24 Idem par 1.

25 Idem par 77

26 Idem par 80.

27 Mupangavanhu supra $\mathrm{n} 13$ at 171.

28 Supra 23 at par 71.

29 Mupangavanhu supra $n 13$ at 171.

30 Hutchison \& Pretorius 23. 
is satisfied that the contract was freely entered into with the intention to create binding obligations, it should uphold and enforce the contract based on the principle of pacta sunt servanda. Accordingly, there should be minimal state intervention in the area of contract law as a result of freedom of contract and party autonomy. Autonomy entails that the decision-maker must accept the responsibility of binding himself to a contract. $^{31}$

Sanctity of contract guarantees certainty in contract law. Courts interfere with contractual provisions agreed upon between the parties only in exceptional cases. ${ }^{32}$ A judge's role is, therefore, equivalent to that of an umpire in a cricket match who must ensure that the game is played according to the rules, in this case according to the terms of the contract. $^{33}$ Accordingly, judges have little judicial discretion as they should recognise and give effect to the agreement reached by the parties. ${ }^{34}$ The discretion of judges in lower courts is also limited as they are not able to depart from the stare decisis rule. ${ }^{35}$ A conservative legal culture, that respects the intricate nature of contract law rules, has developed over time. ${ }^{36}$ Judges are cautious and will not interfere with contractual terms agreed upon by parties. ${ }^{37}$ They also do not permit their personal ideologies, values and sensibilities to feature in the adjudication process. ${ }^{38}$ This results in the occasional enforcement of contracts that are unfair and unjust, to the detriment of the weaker party. ${ }^{39}$ The scale has been tilting in favour of certainty as opposed to fairness. The role of the court is to ensure procedural as opposed to substantive fairness. ${ }^{40}$ It is argued that the modern law of contract should allow judges to be flexible by importing open-ended standards, such as, good faith and reasonableness, to ensure fairness and to protect the weaker party.

Time limitation clauses in insurance contracts and exemption clauses in relation to private health care, are sometimes at odds not only with the value of equality, but also with the values of dignity and freedom. ${ }^{41} \mathrm{~A}$

31 Van der Merwe, Van Huyssteen, Reinecke \& Lubbe Contract General Principles (2012) 9.

32 Sasfin (Pty) Ltd v Beukes 19891 SA 1 (A) par 12; Brisley v Drotsky supra 7 as per Cameron JA par 7; Christie \& Bradfield The Law of Contract in South Africa (2011) 14-15.

33 Hutchison \& Pretorius 23.

34 Van Huyssteen \& Maxwell Contract Law in South Africa (2014) 84.

35 Stare decisis constraints legal reasoning and can lead to judicial conservatism (which can be seen in the Supreme Court of Appeal): Du Bois (ed) Wille's Principles of South African Law (2007) 80. See also Louw 'Yet another call for greater role for good faith in the South African Law of Contract: Can we banish the law of jungle, while avoiding the elephant in the room?' 2013 PER/PEL 4447.

36 Bhana supra n 11 at 311.

37 Barkhuizen $v$ Napier supra $n 7$ at par 70.

38 Bhana supra $\mathrm{n} 11$ at 302

39 Afrox Healthcare Bpk $v$ Strydom supra n 7; Brisley $v$ Drotsky supra $n 7$.

40 Ibid.

41 Hopkins 'Insurance Policies and the Bill of Rights: Rethinking the Sanctity of Contract Paradigm’ 2002 SALJ 155157. 
party in a weak bargaining position has little option but to contract on harsh and oppressive terms, such as time limitation clauses which are normally contained in standard-form contracts. ${ }^{42}$ Such contracts undermine freedom of contract between the contracting parties as they eliminate the opportunity for negotiating terms. ${ }^{43}$ Consumers have no bargaining power to negotiate the terms of the contract and they are imposed on a take-it-or-leave-it basis. ${ }^{44}$ As a result of the disparities in bargaining power, insurance companies are able to insist on the inclusion of time limitation clauses in their contracts. Limiting the time period within which an insured has to challenge repudiation of a policy, is a useful way for insurance companies to reduce the possibility of having to pay out on a claim. ${ }^{45}$ It means that that particular claim is lost if it is not submitted on time since the insured is forever barred from lodging a claim.

Time limitation clauses are generally valid and enforceable based on the Constitutional Court decision in Barkhuizen $v$ Napier. This case dealt with a contractual term that limited the right of access to the courts. Ngcobo J held that the correct approach to the constitutional challenges to contractual terms, is to determine whether the term is contrary to public policy as evidenced by the constitutional values that underlie our constitutional democracy, in particular, those found in the Bill of Rights. ${ }^{46}$ The court developed a two stage enquiry in determining fairness: First, whether the clause itself is unreasonable; and secondly, if the clause is reasonable, whether it should be enforced, taking into account circumstances which prevented compliance with the term. ${ }^{47}$ The argument that enforcement of the time-bar clause would be considered unjust, based on the requirement of good faith, was rejected. The Constitutional Court upheld the time limitation clause. ${ }^{48}$ It was held that public policy would preclude the enforcement of a contractual term in circumstances where such enforcement would be unjust and unreasonable. ${ }^{49}$ By implication, a clause which is so unreasonable that its unfairness is manifest would also not be enforced.

The decision in Brisley $v$ Drotsky also shows that sanctity of contract prevails over the notion of good faith and fairness. This case involved a

42 Ibid.

43 Naude 'The Consumer's "Right to Fair, Reasonable and Just Terms" Under the New Consumer Protection Act in Comparative Perspective' 2009 SALJ 505 529; Mupangavanhu 'Exemption Clauses and the Consumer Protection Act 68 of 2008: An Assessment of Naidoo v Birchwood Hotel 20126 SA 170 (GSJ)' 2014 PELJ 1168 1188; Hutchison \& Pretorius 24-25.

44 The contract does not thus represent the agreement between the consumer and the supplier. See Naude 2009 SALJ 505 529; Mupangavanhu idem 1188.

45 Hopkins supra 41 at 157.

46 Barkhuizen $v$ Napier supra $\mathrm{n} 7$ at par 30.

47 Idem parr 56-59.

48 The Court found that the enforcement of clause 5.2.5 would not be unjust to the applicant (par 86)

49 Barkhuizen $v$ Napier supra $n 7$ at par 73. See also Sasfin (Pty) Ltd v Beukes supra $\mathrm{n} 32$ 
non-variation clause in a lease agreement. Although the parties orally agreed that the lessee could pay rent when it suited her, ${ }^{50}$ the Supreme Court of Appeal (SCA) refused the lessee's reliance on good faith. ${ }^{51}$ It was held that good faith is an abstract value and could thus not be employed by a judge to intervene in contractual relationships. ${ }^{52}$ Just like reasonableness and fairness, good faith underpins and informs the substantive law of contract, shaping its rules and doctrines. ${ }^{53}$ The majority of the judges held that to give judges a discretionary power to disregard contractual provisions on the basis of their personal idiosyncrasies regarding what is fair and reasonable, would give rise to legal and commercial uncertainty. The judges enforced the contract and upheld the shifren principle. ${ }^{54}$ The enforcement was arguably substantively unfair and unjust since the application of the shifren principle allows a party to go back on his or her word, notwithstanding the other party's good reliance on it. ${ }^{55}$

Similarly in Afrox Healthcare Bpk $v$ Strydom, pacta sunt servanda trumped fairness. The respondent went to a hospital and signed a standard-form contract incorporating a clause that excluded liability for any damages suffered as a result of the negligence of the nursing staff or employees of the appellant. ${ }^{56}$ The respondent suffered damages as a result of the negligence of nursing staff. The Court held that it was in the public interest that a contract entered into freely and seriously, by parties having the necessary capacity, should be enforced. ${ }^{57}$ The decision to indemnify the hospital from liability shows that the mere fact that a term is unfair or might operate harshly, does not, in itself, result in the contract being set aside. Even though the case involved a standard-form contract, it was held that there was nothing to prove that the patient had occupied a weaker bargaining position. ${ }^{58}$ The court failed to recognise that the respondent was in a desperate situation of getting medical assistance and was accordingly, not in a conducive environment to contract compared to the appellant. The parties could thus not have been occupying an equal bargaining position since the need to go through with the operation as planned, decreased the patient's bargaining power. ${ }^{59}$

50 Brisley $v$ Drotsky supra $\mathrm{n} 7$ at par 5

51 Idem par 34

52 Idem par 22. See also Kohn "Escaping the "Shifren Shackle" Through the Application of Public Policy: An Analysis of Three Recent Cases Shows Shifren is Not Immutable After All' 2014 Speculum Juris 7483.

53 Hutchison \& Pretorius 32.

54 The principle was developed in SA Sentrale Ko-operatiewe Graanmaatskappy Bpk v Shifren 19644 SA 760 (A).

55 Kohn supra $\mathrm{n} 52$ at 75.

56 Afrox Healthcare Bpk $v$ Strydom supra $\mathrm{n} 7$ at par 3

57 Idem par 34

58 Idem par 12

59 Naude \& Lubbe 'Exemption Clauses - A Rethink Occasioned by Afrox Healthcare Bpk v Strydom' 2005 SALJ 441 461; Bhana \& Pieterse 2005 SALJ 886 
The decision in Afrox has been largely criticised because the patient was only confronted with an exemption clause at the very last minute and it is unrealistic to have expected him to seek a better contract elsewhere. ${ }^{60}$ Non-acceptance of the terms would probably have led to refusal of the required health services. ${ }^{61}$ The patient would likely have been presented with similar terms if he had decided to go to another private hospital. Naude rightly argues that the fact that the exemption clause was contrary to the essence of a contract to obtain medical care, and that it ultimately involves the patient's right to life and bodily integrity, means that the clause is generally substantively unfair. ${ }^{62}$ The exemption offends against the underlying principle of good faith as well as the dignity of the patient. ${ }^{63}$

In Bredenkamp and Others $v$ Standard Bank of South Africa Ltd, ${ }^{64}$ the appellant sought an interdict to restrain the bank from exercising its contractual right to close a customer's bank accounts on reasonable notice. Jajbhay J held that the bank had to exercise this power fairly and for good cause, notwithstanding a provision in a contract allowing the bank to close the account "for no reason" as such a clause did not find support. ${ }^{65}$ The SCA, however, rejected the idea of an overarching requirement of fairness in contract law. ${ }^{66}$ In Maphango $v$ Aengus Lifestyle Properties (Pty) Ltd, ${ }^{67}$ the SCA reinforced the position that reasonableness and fairness are not free-standing requirements for the exercise of a contractual right. ${ }^{68}$ A court can thus not refuse to give effect to the implementation of a contract simply because that implementation is regarded by the individual judge to be unreasonable and unfair. ${ }^{69}$ It is argued that the view that fairness should not be an overarching requirement in contract law, in light of the Constitution and the CPA, is flawed. In a society where there are social and economic disparities, importing fairness as an overarching requirement will force judges to ensure that the enforcement of a contract is not unfair. There is therefore a need to develop fairness so that it becomes a broad requirement of our law in contractual relations. With the death of the exceptio doli generalis in Bank of Lisbon, ${ }^{70}$ fairness could be achieved by developing the principle of good faith. The notion of good faith has an active role to play in ensuring that the law remains sensitive to and in tune with the needs of society. Contracting parties are subject to the values of society when

60 Ibid.

61 Bhana \& Pieterse supra n 18 at 886-887.

62 Naude 2009 SALJ 505510.

63 Naude \& Lubbe 2005 SALJ 441457.

6420104 SA 468 (SCA).

65 Bredenkamp v Standard Bank of South Africa Ltd 20095 SA 304 (GSJ).

66 Bredenkamp v Standard Bank of South Africa Ltd 20104 SA 468 (SCA) parr $30,51 \& 66$.

6720115 SA 19 (SCA).

68 Idem par 23.

69 Idem 25.

70 Bank of Lisbon and South Africa Ltd v De Ornelas 19883 SA 580 (A). 
exercising their private autonomy. ${ }^{71}$ Van de Merwe et al opine that:

The very principles of socio-economic expediency, which in many circumstances support a policy favouring the exact enforcement of contracts freely entered into by consenting parties, may in particular circumstances require that less weight be attached to the ideals of individual autonomy and freedom of action. ${ }^{72}$

The need to balance certainty, fairness and equity cannot be overstressed.

The Constitutional Court in Everfresh Market Virginia $v$ Shoprite Checkers $^{73}$ emphasised the central importance of the principle of good faith and the desirability of infusing the law of contract with constitutional values, including the values of ubuntu. These statements are a source of hope regarding the notion of fairness and equity in contract law. It remains to be seen if the SCA will embrace the pronouncements in Everfresh by developing and expanding the role of good faith.

\section{The Common Law of Contract and the Notion of Fairness}

Unfairness in contract law is dealt with in a number of ways, including the manner in which consensus is obtained; impossibility of performance; ${ }^{74}$ relaxation of the caveat subscriptor rule; and through the contra proferentem rule, ${ }^{75}$ which states that if there is ambiguity, the language must be construed against the proferens. ${ }^{76}$ Naturalia also bring an element of fairness by ensuring that certain terms apply to a particular class of contract by operation of law. ${ }^{77}$ It is based on notions of what is both economically and generally viable, fair and reasonable. ${ }^{78}$ In addition to the above, public policy is generally used to balance sanctity of contract and fairness: For example, a restraint of trade which is unreasonable, is treated as being against public policy and will not be enforced by the courts. ${ }^{79}$ The approach to disputes regarding restraint of trade agreements, requires judges to balance freedom of contract and freedom of trade as it is in the interest of society for its members to be productive. The burden of proof is, however, on the party wishing to escape liability to prove that the restraint of trade agreement is against public policy. ${ }^{80}$ Both freedom and sanctity of contract are thus preferred

71 Van de Merwe, Van Huyssteen, Reinecke \& Lubbe Contract General Principles (2012) 9

72 Idem 9-10.

73 Supra $n 23$

74 Van de Merwe et al 189.

75 Christie \& Bradfield 14

76 Hutchison \& Pretorius 268, Du Bois (2007) 804 \& 805; Mupangavanhu supran 43 at 1174 .

77 Van de Merwe et al 246.

78 Ibid.

79 Idem 185; Hutchison \& Pretorius 196.

80 Magna Alloys and Research (SA) (Pty) Ltd v Ellis 19844 SA 874 (A) 898. 
except where the agreement is unreasonable. ${ }^{81}$

Our common law does not recognise agreements that are contrary to public policy and will declare contracts invalid on that ground ${ }^{82}$ Public policy is rooted in the Constitution and the values that underlie it. ${ }^{83}$ It is informed by the values of ubuntu. ${ }^{84}$ It imports notions of fairness, justice and equity, and reasonableness. ${ }^{85}$ While public policy endorses freedom and sanctity of contract, ${ }^{86}$ it precludes the enforcement of a contractual term in circumstances where such enforcement would be unjust and unreasonable. ${ }^{87}$ The general approach to making fairness and reasonableness the focus of the public policy enquiry, has the potential to balance sanctity of contract with fairness in contract law. Public policy considerations are not static and may change as circumstances change. ${ }^{88}$

The question that arises is whether fairness and equity are fully accommodated under the rubric and scope of public policy. The answer must be in the negative. Public policy needs further development to fully accommodate fairness and equity. ${ }^{89}$ Its current application is lacking in that it usually favours freedom of contract and is based on the understanding that commercial transactions should not be unduly trammelled by restrictions of that freedom. ${ }^{90}$ Public policy has proven up until now not to be an alternative to fairness and will remain this way until its scope and content has accordingly been expanded. Again, its precise prescripts and how exactly they ought to be weighed in the balance in a given case, are matters that have not proven easy to grapple with. ${ }^{91}$ It is argued that public policy has not succeeded in balancing certainty with fairness and equity. Its scope needs to be expanded and developed to be able to fully accommodate fairness and equity. Despite this however, the judgments discussed below indicate that the tide is now turning towards fairness.

In United Reformed Church, De Doorns $v$ President of the Republic of South Africa and Others, ${ }^{92}$ the matter was primarily concerned with the validity of the provisions of clause 16 in the notarial lease agreements.

81 Van de Merwe et al 185.

82 Sasfin (Pty) Ltd $v$ Beukes supra 32 at pars 8 and 9

83 Barkhuizen v Napier supra $\mathrm{n} 7$ at par 28. Hopkins 2002 SALJ 155172

84 Barkhuizen $v$ Napier supra $n 7$ at par 51; Everfresh Market Virginia (Pty) Ltd $v$ Shoprite Checkers (Pty) Ltd supra n 23 at par 51.

85 Barkhuizen $v$ Napier supra $n 7$ at parr $51 \& 73$. See also Bredenkamp $v$ Standard Bank of South Africa Ltd supra n 87 at par 38.

86 Hutchison \& Pretorius 30; Christie \& Bradfield 359; Sasfin (Pty) Ltd v Beukes supra $\mathrm{n} 32$ at par 13.

87 Barkhuizen $v$ Napier supra $n 7$ at parr $70 \& 73$; Sasfin (Pty) Ltd $v$ Beukes supra $\mathrm{n} 32$ at par 12; Du Bois 763.

88 Bredenkamp v Standard Bank of South Africa Ltd supra $n 87$ at par 38.

89 Brand 2009 SALJ 7187.

90 Sasfin (Pty) Ltd $v$ Beukes supra 32 at par 13.

91 Kohn supra $\mathrm{n} 52$ at 75.

92 United Reformed Church, De Doorns $v$ President of the Republic of South Africa and Others 20135 BCLR 573 (WCC). 
The clause obliged the applicant to transfer its three properties, free of charge, to the first respondent after the expiry of the lease. The question before the Court was whether the provisions of clause 16 offend public policy. ${ }^{93}$ The applicant contended that at the time of the conclusion of the lease agreements, it was in a weaker position than the state, with the result that it was forced to conclude the agreements which contained terms that were largely biased in favour of the state. The second contention was that the provisions of clause 16 violate section 25 of the Constitution. Zondi J stated that:

... in determining the weight to be attached to the values of freedom and dignity and equality the extent to which the contract was freely and voluntary concluded will be a vital factor ${ }^{94} \ldots$ the role of the courts is not merely to enforce contracts but also to ensure that a minimum degree of fairness which include consideration of the relative position of the contracting parties, is observed ... 95

Unequal bargaining power is a relevant consideration in determining whether a contractual term is contrary to public policy. ${ }^{96}$ The High Court held that the applicant had succeeded in showing that it was in a weaker bargaining position than the Department of Local Government. ${ }^{97}$ The terms had been dictated to them and the applicant had little option but to accept. ${ }^{98}$ It was further held that clause 16 of the lease agreements was unfair and, therefore, contrary to public policy insofar as it sought to deprive the applicant of its properties without creating an obligation on the third respondent to pay compensation. ${ }^{99}$ Clause 16 was found to be inimical to the values enshrined in the Constitution. ${ }^{100}$ The provision was "unnecessary overbroad" and "a disguised form of expropriation" that could not be allowed to stand. ${ }^{101}$ Accordingly, the provisions of clause 16 were declared void and unenforceable. ${ }^{102}$ The Court held that the applicant was entitled to receive consideration to be agreed upon between the parties, alternatively fair compensation should the properties be transferred to the state. ${ }^{103}$

Similarly, the High Court in Naidoo $v$ Birchwood Hotel ${ }^{104}$ declined to enforce exemption clauses and the disclaimer notices on the basis that doing so would have been unjust and unfair. ${ }^{105}$ The plaintiff instituted a delictual claim against the defendant for the serious injuries he sustained when a gate fell on top of him while trying to exit the hotel. The issue to

93 Idem parr $24 \& 31$.

94 Idem par 33

95 Idem par 34 (own emphasis).

96 Ibid.

97 Idem par 35

98 Ibid.

99 Idem par 40.

100 Ibid.

101 Idem par 41.

102 Idem par 44.

103 Ibid.

104 Naidoo v Birchwood Hotel 20126 SA 170 (GSJ).

105 Idem par 53. 
be determined by the Court was whether the defendant was liable for the bodily injuries sustained by the plaintiff. ${ }^{106}$ The plaintiff's case was founded on the premise that the defendant had been negligent and that it could have prevented the harm from occurring. Nicholls J stated that exemption clauses that exclude liability for bodily harm in hotels and other public publics have the effect, generally, of denying a claimant judicial redress. ${ }^{107}$ The Court observed that:

Naidoo was a guest in a hotel. To enter and egress is an integral component of his stay. A guest in a hotel does not take his life in his hands when he exits through the hotel gates. To deny him judicial redress for injuries he suffered in doing so, which came about as a result of the negligent conduct of the hotel, offends against notions of justice and fairness ... ${ }^{188}$

The Court concluded that Naidoo had discharged his onus of proving a delictual claim against the hotel and that the disclaimer notices and the exemption clauses were not a good defence. ${ }^{109}$

The Constitutional Court in Botha $v$ Rich $^{110}$ had to determine whether the respondents were obliged, in terms of section 27(1) of the Alienation of Land Act 68 of 1968, to register the transfer of the property in the name of the first applicant after more than half of the purchase price of the immovable property had been paid. ${ }^{111}$ Alternatively, the matter concerned whether enforcement of the cancellation clause was unreasonable, unfair and unconstitutional and if so, whether the applicant was entitled to restitution of the amount paid. The question, therefore, was whether the purchaser's demand for the transfer of property, in terms of section $27(1),{ }^{112}$ could be refused by the seller. ${ }^{113}$ The applicants contended that the enforcement of the cancellation clause in the circumstances would be contrary to public policy. ${ }^{114}$ In granting leave to appeal, the Constitutional Court stated that it was of public importance to determine whether cancellation of a contract governed by the Act, and the resultant forfeiture of the payments of more than half

106 Idem par 3

107 Idem par 52.

108 Idem par 53.

109 Idem par 54.

110 Botha v Rich 20144 SA 124 (CC).

111 Idem par 2.

112 It reads: "Any purchaser who in terms of a deed of alienation has undertaken to pay the purchase price of land in specified instalments over a period in the future and who has paid to the seller in such instalments not less than 50 per cent of the purchase price, shall, if the land is registrable, be entitled to demand from the seller transfer of the land on condition that simultaneously with the registration of the transfer there shall be registered in favour of the seller a first mortgage bond over the land to secure the balance of the purchase price and interest in terms of the deed of alienation".

113 Botha $v$ Rich supra $\mathrm{n} 110$ at par 23.

114 Idem par 19. 
the purchase price of the property, was fair and thus constitutionally compliant. 115

The application for cancellation failed on the basis that forfeiture, in circumstances where three-quarters of the purchase price has already been paid, would have been a disproportionate penalty for breach. ${ }^{116}$ The Court ordered the respondents to sign all necessary documents to effect the registration and to transfer the property concerned into the name of the first applicant. ${ }^{117}$ It also ordered the first applicant to pay all arrears owing, outstanding levies and to secure the balance of the purchase price plus interest in terms of the sale agreement. ${ }^{118}$

The importation of section 27(1) into the instalment sale agreement afforded the applicant protection who otherwise could have been prejudiced by the cancellation of the contract and the forfeiture of the monies paid. The interpretation of section 27(1) by the Constitutional Court is laudable as it is consistent with the objective of the Constitution that contracting parties should be treated with equal worth and concern. ${ }^{119}$ It validates fairness. To deprive the first applicant of the opportunity to have the property transferred to her and in the process cure her breach in regard to arrears, would have been a disproportionate sanction and consequently unfair. ${ }^{120}$ It would also have been equally disproportionate to allow registration of transfer without making that registration conditional upon payment of the arrears and the amounts outstanding in municipal rates, taxes and service fees. ${ }^{121}$

The three judgements discussed above illustrate the developments that are taking place in balancing the principle of freedom of contract, and the counter-principle of social control over private volition in the interest of public policy. The judgements mark a significant stride towards fairness and equity in contractual relationships. The need to legislate against contractual unfairness, unreasonableness, unconscionability or oppressive contractual provisions, ${ }^{122}$ however, remains crucial particularly in light of the inherent limits of judicial control. ${ }^{123}$ Legislative intervention would protect consumers by ensuring that they are not exploited or abused in the marketplace. The relevant provisions of the CPA are examined below.

115 Idem par 24

116 Idem par 51

117 Idem par 53.

118 Ibid.

119 Idem par 40

120 Idem par 49.

121 Ibid.

122 Barkhuizen $v$ Napier supra $\mathrm{n} 7$ at par 170.

123 Naude 'Unfair Contractual Term Legislation: The Implications of Why We Need it for its Formulation and Application' 2006 Stell LR 361384. 


\section{The Importance of the Consumer Protection Act}

\section{Introduction}

The CPA attempts to achieve a balance between relevant principles and policies so as to satisfy prevailing perceptions of justice and fairness, as well as economic, commercial and social expediency. ${ }^{124}$ The CPA gives precedence to the constitutional values of dignity and equality. A contract forms part of the fabric of society and as such, exists and functions within the realm of the values and interests of society. ${ }^{125}$ Consumer protection is particularly important if there are inequalities in bargaining power between the supplier and the consumer. ${ }^{126}$ The pursuit of social justice warrants intervention, especially in South Africa where poverty and inequalities are a reality. 127

The Constitution recognises the imbalances of the past ${ }^{128}$ and the CPA is in accordance with the objective of the Constitution to address the social and economic inequalities brought about by apartheid and the discriminatory laws. ${ }^{129}$ The CPA was enacted to protect illiterate, poor, ignorant and vulnerable people from abuse and exploitation in the marketplace. ${ }^{130}$ The purpose of the CPA is, inter alia, to advance the social and economic welfare of consumers in South Africa, by establishing a legal framework for the achievement and maintenance of a consumer market that is fair, accessible and efficient. It also promotes fair business practices, and protects consumers from unconscionable, unreasonable, unjust or improper trade practices.

The formal rules embedded in contract law have not been flexible enough to cope with the complexities of modern society. ${ }^{131}$ South African legal tradition respects and promotes party autonomy ${ }^{132}$ and judges have thus failed to enjoy any discretion in the application and interpretation of legal norms. Courts have been both slow and hesitant in making the shift from the formal logic of the common law method to the purposive public interest orientated reasoning. ${ }^{133}$ The legislature had to step in, by introducing the CPA, as the need for substantive justice was

124 Van de Merwe et al 10.

125 Idem 12.

126 Hawthorne "The "New Learning" and Transformation of Contract Law: Reconciling the Rule of Law with the Constitutional Imperative to Social Transformation' 2008 SAPR/PL 7782.

127 Preamble CPA. See also Hawthorne 'Responsive Governance: Consumer Protection Legislation and its Effect on Mandatory and Default Rules in the Contract of Sale' 2011 SAPL 432 447; Hawthorne 2008 SAPR/PL 7781.

128 Preamble Act 108 of 1996

129 Preamble CPA.

130 Ibid.

131 Hawthorne supra n 126 at 86

132 Idem 85.

133 Idem 86. 
compelling. ${ }^{134}$ Hawthorne argues that consumer law has caused disintegration of traditional orthodox contract law, as an autonomous system of law, since its implicit acknowledgement of the reality of inequality undermines one of the unwritten cornerstones of classical contract. ${ }^{135}$ Contracting parties can no longer require their agreement to be allowed to function in a legal sphere of its own, outside the encompassing influence of the Constitution and other relevant statutes such as the CPA. ${ }^{136}$

\section{The Consumer Protection Act: An Instrument for Fairness and Equity?}

There are conditions that are prohibited outright with the result that they are void to the extent of their non-compliance with the CPA. Section 51 lists the forms of transactions, agreements, terms or conditions that are prohibited. These are, first, terms aimed at defeating the purposes and policy of the CPA. Secondly, terms misleading or deceiving the consumer; or subjecting the consumer to fraudulent conduct. ${ }^{137}$ Thirdly, terms that directly or indirectly purport to waive or deprive a consumer of a right, and terms that set aside or override the effect of any CPA provision or rather authorise the supplier to do anything that is unlawful. Fourthly, a term that purports to limit or exclude the liability of a supplier for harm caused by gross negligence as well as a term that constitutes an assumption of risk by the consumer or imposes an obligation on a consumer to assume the risk of handling any goods. ${ }^{138}$ Lastly, a term that falsely expresses an acknowledgement by the consumer that no warranties or misrepresentations were made in connection with the agreement is also proscribed in terms of the CPA. ${ }^{139}$

It is worth noting that the CPA makes explicit liability for gross negligence. ${ }^{140}$ By implication, ordinary liability may still be excluded by means of an appropriately worded exemption clause, provided that the exemption has been signed or initialed by the consumer. ${ }^{141}$ Such clauses may, however, be unfair "regardless of whether the consumer knew about them at the time of concluding the contract and signed next to them". ${ }^{142}$ They may involve the consumer's fundamental rights to bodily integrity and life. ${ }^{143}$ The consumer's bargaining power is also fatally impaired if, for example, an exemption clause is drawn to his attention at a very last stage when he had made all the arrangements to be

134 Ibid.

135 Idem 85.

136 Van de Merwe et al 12.

137 S 51 (1) (a).

$138 \mathrm{~S} 51$ (1) (c).

139 S 51 (1) (g).

$140 \mathrm{~S} 51$ (1) (c)

141 Hutchison \& Pretorius 34; Mupangavanhu supra n 43 at 1185

142 Naude 2009 SALJ 505510.

143 Ibid 
admitted to a hospital ${ }^{144}$ or to go on holiday.

Where contractual terms are not prohibited outright by the CPA, they are subjected to the requirement of fairness and reasonableness. Section 48 of the CPA deals with the consumer's right to fair, just and reasonable terms and conditions. It should be read in conjunction with the rest of part $\mathrm{G}$ as well as with regulation 44 that lists contract terms that are presumed to be unfair. ${ }^{45}$ Regulation 44 only applies where the consumer is a natural person who bought goods for private purposes. ${ }^{146}$ A supplier must not supply or offer to supply any goods or services at a price or subject to a term that is unfair, unreasonable or unjust. ${ }^{147}$ Any marketing or negotiations, for the purpose of entering into transactions for the supply of goods or services, must also be done in a manner that is fair, reasonable and just. In addition to the above, a supplier must not require a consumer to waive any rights, assume any obligation, or waive any liability of the supplier on terms that are unfair, unreasonable or unjust. ${ }^{148}$ Further, a supplier may not impose such terms as a condition of entering into a transaction. ${ }^{149}$

The CPA explains the meaning of a term that is unfair, unreasonable or unjust as a term that is: First, excessively one-sided in favour of the supplier; secondly, is so adverse to the consumer as to be inequitable; and thirdly, was induced by a supplier's false, misleading or deceptive misrepresentations. ${ }^{150}$ It has, however, been argued that the test for unfairness set out in section $48(2)$ is not applicable to price. ${ }^{151}$ Courts will thus have to create such a test themselves taking into account the factors listed in section 52(2) of the CPA which include, inter alia, the fair value of the goods or services in question; the conduct of the supplier and the consumer respectively; whether there was any negotiation between a supplier and the consumer, and if so, the extent of that negotiation as well as the extent to which any documents relating to the transaction satisfied the plain language requirement.

Although the legislature tried to give some indication as to their meaning of "unfair", "unreasonable" and "unjust", it failed not only to clearly and comprehensively define the words, but also to provide a guideline regarding the interpretation of these concepts. ${ }^{152}$ An interpretation that gives effect to the CPA's purposes would be crucial so

$144 \mathrm{Ibid}$. See also Afrox Healthcare supra $\mathrm{n} 7$.

145 Barnard The Influence of the Consumer Protection Act 68 of 2008 on the Common Law of Sale (LLD dissertation 2013 UP) 133.

146 Ibid. See also reg 44 (1) CPA.

147 S 48 (1) (a)

148 S 48 (1) (c)

$149 \mathrm{~S} 48$ (1) (c)

$150 \mathrm{~S} 48$ (2) (c) read with s 41.

151 Van Eeden A Guide to the Consumer Protection Act (2009) 84-185. See also Barnard supra $\mathrm{n} 167$ at 134

152 Christie \& Bradfield 21; Hawthorne 2011 SAPL 432 439; Naude 2009 SALJ 505516. 
that consumers are afforded the intended protection. It is hoped that case law will provide direction in the near future. ${ }^{153}$

Section 49 of the CPA deals with notice required for certain terms and conditions. It requires that any notice or provision that purports first, to limit in any way the risk of the supplier; secondly, to constitute an assumption of risk by the consumer; thirdly, impose an obligation on the consumer to indemnify the supplier; or lastly to be an acknowledgement of any fact by the consumer, ${ }^{154}$ to be drawn to the attention of the consumer in a conspicuous manner and form that is likely to attract the attention of an ordinary alert consumer, having regard to the circumstances. ${ }^{155}$

The fact, nature and effect of the provision must be drawn to the consumer's attention before she has entered into the transaction, begins to engage in the activity, gains access to the facility, or is required to offer consideration for the transaction. ${ }^{156}$ The consumer's attention must also be drawn to any provision or notice which concerns any activity that is subject to any risk of an unusual character, the presence of which the consumer could not reasonably be expected to be aware of, or which an ordinary alert consumer could not reasonably be expected to notice or to contemplate in the circumstances, or that could result in serious injury or death. ${ }^{157}$ The consumer must assent to that provision or notice by signing to show his acknowledgement and acceptance of the provision. ${ }^{158}$ The consumer must also be given adequate opportunity in the circumstances to receive and comprehend the provision or notice. ${ }^{159}$ The requirements of section 49 are meant to ensure that consumers are given the opportunity to make informed decisions. ${ }^{160}$ A term is also construed as unfair, unreasonable or unjust where its existence, nature and effect were not adequately drawn to the attention of the consumer in a clear and conspicuous manner before the transaction was entered into. ${ }^{161}$

Part $\mathrm{F}$ of the CPA provides for the right to fair and honest dealing. It focusses on unconscionable conduct and false, misleading or deceptive representations. ${ }^{162}$ The making of false, misleading or deceptive representations, concerning a material fact to a consumer, is prohibited. ${ }^{163}$ In terms of the common law of contract, the grounds that render a contract voidable are duress, undue influence, misrepresentation and commercial bribery. An innocent party can thus

153 Hawthorne 2011 SAPL 432 439; Naude 2009 SALJ 505516.

154 S 49(1).

155 S 49(4)(a).

156 S 49(4)(b).

157 S 49(2).

158 Ibid.

159 S 49(5).

160 Mupangavanhu supra n 43 at 1180 .

161 S 48(2)(d) read with s 49(4).

162 Ss $40 \& 41$.

163 S 41 (a). 
choose to rescind or affirm the contract and claim damages if he has suffered patrimonial loss. Although the CPA incorporates the same grounds provided in terms of the common law, it also includes physical force against a consumer, pressure or harassment, unfair tactics or any other similar conduct when marketing, supplying, negotiating, concluding or executing an agreement to supply any goods or services to a consumer. ${ }^{164}$ In terms of the common law, the use of physical force, for example where X grabs B's hand and forces him to sign, does not give rise to a contract since $B$ has not acted at all. ${ }^{165}$ In terms of the common law, "pressure" forms part of duress and is not an independent ground for setting aside a contract. It remains to be seen whether a contract can be set aside solely on the basis of "pressure ... harassment or unfair tactics". 166

In addition, the CPA clearly provides that:

... it is unconscionable for a supplier knowingly to take advantage of the fact that a consumer was substantially unable to protect the consumer's own interest because of physical or mental disability, illiteracy, ignorance, inability to understand the language of an agreement. ${ }^{167}$

The supplier may not, therefore, profit from the ignorance or weaknesses of the consumer as such conduct is "unconscionable".

\section{Commentary}

Although the common law of contract is trying to establish a balance between the sanctity of contract on the one hand, and the interests of the weak contracting party on the other hand, the balance has not yet been achieved. The CPA, together with the Constitution, is nonetheless exerting a strong impact upon contract law. The provisions of the CPA are likely to force courts to reshape the established principles and doctrines of contract law so that they can be in conformity herewith. Most problems in contract law exist due to its classical nature, socioeconomic factors, patriarchy and historical factors. Inequalities in bargaining power appear to be inherent in contractual relationships because of social differences and the unequal distribution of wealth. The CPA creates mechanisms through which problems experienced in contract law could be ameliorated by introducing prerequisites for consumer contracts, such as plain language and the need for the attention of the consumer to be drawn to certain clauses. ${ }^{168}$ The CPA also attempts to address terms that are unfair, unjust and unreasonable, but it does not cover every area; thus the criticisms levelled against contract law are only partially addressed.

164 S 40(1).

165 Hutchison \& Pretorius 136.

166 S 40.

$167 \mathrm{~S} 40(2)$.

168 Ss $22 \& 49(4)$. 
Although the provisions of the CPA dealing with improperly obtained consensus overlap considerably with the common law, Hutchison and Pretorius rightly argue that the substantive provisions of the CPA go further than the existing common law. ${ }^{169}$ The procedures laid down for their enforcement are also different. Christie and Bradfield argue that: "It may be that the real value in the legislation lies rather in the mechanisms that it has introduced for the relatively more accessible and informal resolution of consumer disputes". 170

A consumer may approach an ombud, the consumer courts, the National Consumer Commission and the National Consumer Tribunal to obtain relief. ${ }^{171}$ The fact that consumers still enjoy their common law remedies together with the other forms of relief, which can be obtained in the various consumer protection institutions, is a remarkable development in the South African legal system. The importance of the enactment of the CPA thus cannot be underestimated.

Nonetheless, the enactment of the CPA does not mean that the law has achieved perfection. ${ }^{172}$ The CPA has numerous shortcomings, inter alia, it fails to provide guidelines for the interpretation of key concepts, such as, "fairness", "reasonableness" and "justice". Naude rightly opines that the provisions dealing with unfair contractual terms are lacking in some respects, with the result that the problems faced by consumers have not been sufficiently addressed in accordance with international best practices. ${ }^{173}$ Therefore, Naude recommends that the legislature and the Department of Trade and Industry make amendments to the CPA which would include an explicit provision that allows courts to raise the issue of unfairness on their own initiative. ${ }^{174}$

Hawthorne argues that the effectiveness of the CPA is undermined by its failure to introduce mandatory rules to avoid reliance on default rules. ${ }^{175} \mathrm{He}$ concludes that the introduction of a new definition for "defect" may not facilitate the seamless absorption of the CPA into the law of contract, and that it will have a limited impact on the law of sale. ${ }^{176}$ It has also been argued that, viewed from the perspective of contractual mistake, the CPA does not provide consumers with much protection; ${ }^{177}$ what it gives with the one hand it takes with the other, in relation to exemption clauses. ${ }^{178}$ This is because the CPA requires that the fact, nature and effect of any notice, that purports to limit the liability of the supplier, be drawn to the attention of the consumer in a

169 Hutchison \& Pretorius 144.

170 Christie \& Bradfield 22.

171 Ss $69,70 \& 71$

172 Christie \& Bradfield 12

173 Naude 2009 SALJ 505-506

174 Idem 536

175 Hawthorne 2011 SAPL 432448

176 Ibid.

177 Pretorius ‘Exemption Clauses and Mistake: Mercurius Motors v Lopez 20083 SA 572 (SCA)' 2010 THRHR 491500

178 Mupangavanhu supra $\mathrm{n} 43$ at 1182. 
conspicuous manner and form that is likely to attract the attention of an ordinary alert consumer. The implication of this provision is that once the supplier has alerted the consumer, he cannot rely on iustus error as in the past. ${ }^{179}$ It is noteworthy that there is scope to amend the CPA after the gaps herein, which can potentially prejudice consumers, have been identified.

Fairness is a slippery concept which is not easy to attain. On its own, the CPA will not suffice in achieving fairness. It must be seen as a step towards building a system that values fairness and equity. Courts, accordingly, should continue to gradually develop common law by infusing contract law doctrines with constitutional values. The problem of unfair contracts is not only limited to consumer agreements but permeates the whole of contract law. The problem of unfair contractual terms and the abuse of freedom of contract by a stronger party may persist in the rest of contract law, and needs to therefore be abated. It is argued that fairness should be an overriding requirement in all contracts to ensure that freedom and sanctity of contract do not always prevail over fairness and equity. South African society needs to promote fairness to the extent that the duty to act in good faith should be the expected standard; anything less ought to be contrary to community expectations. The values of ubuntu, which "inspire much of our constitutional compact", ${ }^{180}$ require fairness in contract law since "it carries in the ideas of humaneness, social justice and fairness". ${ }^{181}$

\section{Conclusion}

The enactment of the CPA, aimed at protecting public interests, reinforces the need to incorporate the societal values such as fairness, justice, and equality into contract law. The CPA is of particular significance insofar as the protection and regulation of consumer transactions are concerned. The fact that it has shortcomings, does not detract from its importance in ensuring that consumers' rights are recognised and respected by suppliers when entering into or executing a contract. The argument that provisions dealing with unfair contractual terms needs to be amended, is pertinent to the realisation of consumer rights in South Africa. The CPA, however, will not adequately address the problem of unfairness in contract law. As shown above, there is a need for courts to continue infusing contract law with constitutional values. By developing and expanding concepts such as, good faith and ubuntu, the problems of unfairness and inequality will be ameliorated. Alternatively, courts should expand and develop public policy to include good faith in order to import fairness into contract law.

179 Idem 1181; Pretorius 2010 THRHR 491500.

180 Everfresh Market Virginia (Pty) Ltd $v$ Shoprite Checkers (Pty) Ltd supra $n 23$ at par 71.

181 Ibid. 